\title{
Böbrek Hücreli Karsinomda Risk Faktörleri ve Etyoloji
}

\section{Risk Factors and Etiology in Renal Cell Carcinoma}

\author{
Dr. Ümit Gül \\ Başkent Üniversitesi Tıp Fakültesi, Üroloji Anabilim Dalı, Adana, Türkiye
}

\begin{abstract}
Özet
Böbrek Hücreli Karsinom (BHK) üçüncü en sık ürolojik kanser olup daha erken evrede tanı konulmasına rağmen halen yüksek mortalite oranları ile seyretmektedir. Görülme sıklığı gittikçe artmaktadır. Etyoloji ve risk faktörlerinin daha iyi tanımlanması için yapılan epidemiyolojik çalışmalar hastalığın gelişmesini önlemede alınacak önlemler konusunda bize yeni bilgiler sunacaktır. BHK'da bilinen en güçlü risk faktörleri tütün kullanımı, obezite, ve kan basıncı yüksekliğidir. Ilaç kullanımı ile BHK arasında zayıf, diyet ve mesleki faktörler ile BHK arasında ise orta derecede güce sahip ilişki ortaya konulabilmiştir. Risk faktörlerinin daha güçlü kanıtlarla ortaya konulabilmesi daha etkin tedbirlerin alınmasını sağlayacaktır. Risk altındaki insanların belirlenerek gerekli bilgilendirilmelerin yapılması ve önlemlerin alınması ile BHK gelişme riskinde azalma hedeflenebilir. (Üroonkoloji Bülteni 2014;13:135-138)
\end{abstract}

Anahtar Kelimeler: Böbrek kanseri, risk faktörleri, tütün kullanımı

\begin{abstract}
Summary
Renal cell carcinoma (RCC) is the third most common urological carcinoma and has the highest mortality rate although it is diagnosed at the early stage. The incidence of RCC has been increasing. Epidemiological studies conducted to better clarify the etiology and risk factors will shed new light about protective measures in prevention. The strongest known risk factors related to RCC are tobacco smoking, obesity and high blood pressure. A weak correlation was found between medications and RCC and a moderate correlation was found between occupational and dietary factors and RCC. Establishing correlations with stronger proofs between risk factors and RCC might lead to more effective preventive measures. Identification of people under risk and informing them adequately and establishing protective measures may lead to a decrease in the risk of RCC development. (Bulletin of Urooncology 2014;13:135-138)
\end{abstract}

Key Words: Kidney cancer, risk factors, tobacco smoking

\section{Giriş}

Böbrek tümörleri malign, benign veya enflamatuar karakterde olabilir. Malign böbrek tümörlerinin yaklaşık \%85-\%90'ını böbrek hücreli karsinomdur (BHK). Ürolojik kanserler arasında prostat ve mesane kanserinden sonra üçüncü sıklıkta görülür. BHK tüm erişkin kanserlerinin yaklaşık \%2-\%3'ünü oluşturur (1). Böbrek tümörü görülme sıklığında Danimarka ve İsviçre'de bir azalma görülmekle birlikte son 20 yılda dünya genelinde ve Avrupada yıllık \%2'lik artış söz konusudur (2). Avrupa Birliği'nde 2012 yılında 84400 yeni BHK olgusu ve 34700 ölüm bildirilmiştir (3). Görüntüleme yöntemlerinin yaygın kullanılması ile tanı konulma sıklığı artmakta ve daha küçük tümörlere daha erken evrede tanı konulmaktadır $(4,5,6)$. Daha erken evrede tanı konulmasına rağmen mortalitesi belirgin ölçüde azalmamıştır (7). Mortalitesi en yüksek ürolojik kanserdir (\%30-\%40). Böbrek kanseri için Amerikan Kanser Derneği'nin 2014 için en son tahmini yaklaşık 63,920 yeni olgu (39,140'ı erkek, 24,780'i kadın) ve 13,860 kişinin (8900'ü erkek ve 4960'ı kadın) bu hastalıktan öleceğidir. Bu rakamlar, böbrek ve renal pelvisin tüm kanser türlerini kapsamaktadır (8).

BHK ileri yaş hastalığıdır. En sık görüldüğü yaş aralığı 70-74 yaşlarıdır. Erkeklerde kadınlara göre yaklaşık 2:1 oranında daha sık görülmektedir $(9,10)$. Dolayısıyla erkeklerde risk kadınlara göre daha yüksektir. Hastaların büyük çoğunluğu sporadik olup $\% 2$ olgu ise aileseldir (11). Birinci derece akrabasında BHK olan kişilerde riskin 4,3 kat arttığı ortaya konulmuştur (12).

Tütün kullanımı, obezite, ve kan basıncı yüksekliği BHK gelişmesinden sorumlu en güçlü risk faktörleridir $(11,13,14,15,16)$.

\section{Tütün Kullanımı}

Tütün kullanımı hipoksik durumlara yol açarak BHK oluşmasına neden olan hücresel yolakların aktivasyonuna neden olmaktadır. Ayrıca tütün içerisinde bulunan bir çok karsinojenik (polycyclic aromatic hydrocarbonlar, aromatic aminlerheterocyclic aminler, $\mathrm{N}$-nitrosamin) maddenin tümör gelişimini hem başlatabildiği hemde ilerlemesine neden olabildiği bilinmektedir. Beşi kohort 
çalışma, on dokuzu olgu kontrol çalışmasından oluşan toplam yirmi dört çalışmanın değerlendirildiği bir meta-analizde her iki cinste tütün kullanımı, incelenmiş, tütün kullananlar ile kullanmayanlar karşılaştırılmıştır. Sonuç olarak tütün kullanımı artmış BHK görülme riski ile ilişkili bulunmuştur. Bu çalışmada erkeklerde \%54, kadınlarda \%22 artmış risk rapor edilmiştir (17). Bir başka çalışmada tütün kullanan kişilerde kontrollere göre BHK riski 1,6 ile 2,5 kat artmıştır (18). Risk artışında her türlü tütün kullanımı suçlanmaktadır. Ayrıca risk kümülatif doz ile paralel artış gösterir. Tütün kullanımını bırakma durumunda risk düşer. Ancak hiç tütün kullanmamış birinin risk düzeyine ulaşması yıllar (>10 yıl) alır $(17,19)$. Pasif içicilikte artmış risk ile ilişkili bulunmuştur (19).

\section{Obezite}

Obez insanların BHK yakalanma riski obez olmayanlara göre daha fazladır. BHK'nın daha sık teşhis edilmesi dünyada obezitenin yaygınlaşması ile paralel gitmiş̧ir. Bu ilişki yapılan çalışmalarlada ortaya konulmuştur (14). Ayrıca, Asya ülkelerinde insanların vücut kitle indeksleri (VKI) daha düşük olup buralada BHK sıklığının da daha düşük olması bu ilişkiyi daha güçlü bir şekilde ortaya koymaktadır (20). BHK gelişme riski burada da doza bağımlı olup VKI 30 ve üzerinde olanlarda risk 2,5 kat artarken, 25-30 aralığında olanlarda risk 1,5 kat artmaktadır (21). Obezite ile BHK ilişkisi incelendiğinde, VKI'sindeki her $5 \mathrm{~kg} / \mathrm{m} 2$ artış için BHK riski erkeklerde 1,24, kadınlarda 1,34 kat artış gösterir (22). Obezite ve yüksek kan basıncı ile BHK ilişkisini açıklayacak değişik mekanizmalar üzerinde çalışılmıştır. Bu kişilerde lipid peroksidasyonunun arttığı ve bunu artmış BHK gelişme riskini açıklayabileceği ileri sürülmüştür (23). Ayrıca seks steroid hormonlarının renal hücrelerin büyümesi ve çoğalmasını direkt reseptör üzerine etki ederek arttırması, reseptör konsantrasyonlarının düzenlenmesi ya da epidermal büyüme faktörü gibi parakrin faktörler üzerinden açıklanmaya çalışılmıştır. Düşük adiponektin düzeylerine BHK'lı hastalarda sağlıklı insanlara göre daha sık rastlanmaktadır. Obezite ile inflamasyon ve insulin direnci gelişmesi arasında bağlantılar bulunmuştur (24).

\section{Kan Basıncı Yüksekliği}

Kan basıncı yüksekliği ile BHK arasındaki ilişki çeşitli çalışmalarla irdelenmiştir. Anti hipertansif ilaçların, özellikle de diüretiklerin proksimal tübül üzerine etkili olmaları ve BHK'nında daha çok buradan gelişmesi nedeniyle bu ajanların kullanımının BHK'nın potansiyel sebeplerinden olabileceği (25) ileri sürülmesine rağmen kanıtlanmamıştır (26). Literatürde bu konuda görüş birliği yoktur.

Weikert ve ark.'nın yaptığı önemli bir Avrupa çalışmasında arteriyel kan basıncı yüksek ( $\geq 160 \mathrm{mmHg}$ ) olanlar ile düşük $(<120 \mathrm{mmHg})$ olanlar karşış̧tırmış. Kan basıncı yüksekliği olanlarda BHK gelişme riskinin 2,4 kat fazla olduğunu saptamışır (27).

Chow ve ark.'nın yaptığı çalışmada kan basıncı yüksekliği ile BHK gelişme riski arasında doza bağımlı bir ilişkinin olduğu ve kan basıncının düşürülmesi ile riskin zamanla azalabileceği gösterilmiştir (28).

\section{İlaçlar}

Daha önceki bölümde tartışıldı̆ı gibi antihipertansif ilaçların kullanımının BHK sebep olması konusunda kanıtlar yetersizdir.
Bazı analjeziklerin kullanımının etkisi tartışımış bunlarda kanıtlanamamıştır. Tarihsel olarak fenasetin kullanımının böbrek toplayıcı sisteminde değişici epitel hücreli karsinom gelişimini arttırdığı gösterilmiş ancak BHK gelişimine etkisi ortaya konulamamışır (29). Bir olgu kontrol çalışmasında parasetamol ve asetil salisilik asit kullanımının BHK gelişiminde rolü olmadığını ortaya koymuştur (30).

\section{Fizik Aktivite}

Fizik aktivite ile BHK arasındaki ilişki incelendiğinde hem mesleki (31) olarak hem de eğlence (32) amaçlı fizik aktivitenin riski azalttığı görülmüştür.

\section{Beslenme ile iliş̧kili Faktörler}

Faramawi ve ark.'nın yaptığı 13 olgu kontrol çalışmasının metaanalizinde fazla et tüketimi (kırmızı et, kümes hayvanları ve işlenmiş et) artmış böbrek kanseri riski ile ilişkili bulunmuştur. Daha az et tüketenlere göre daha fazla et tüketenlerde riskin \%20-\%30 arttı̆̆ı belirtilmiştir. Et tüketiminin azaltılmasının genel popülasyonda böbrek kanseri insidansını azaltmasında önemli bir yaklaşım olacağı vurgulanmaktadır. Buna karşılık Lee ve arkadaşları 13 prospektif çalışmanın sonuçlarını incelediklerinde kırmızı et, işlenmiş et, kümes hayvanları ve deniz ürünlerinin tüketilmesinin BHK ile ilişkisinin olmadığı sonucuna ulaşmışlardır (33). Ayrıca büyük bir prospektif Avrupa çalışmasıda bu sonucu desteklemektedir (34).

Diyette anti-oksidan alımının riski azaltabileceği öngörülmekle beraber bu konudaki bilimsel kanıtlar henüz yeterli değildir. Lee ve ark.'nın yaptığı çalışmada meyve ve sebzeden zengin beslenmenin riski azalttığını (35) bildirmelerine rağmen böyle bir ilişkinin bulunamadağını ifade eden çalışma da vardır (36). Galeone ve ark.'nın yaptığı çalışmada ise glisemik indeksi yüksek gıdalarla beslenmenin BHK gelişme riskinin 2,56 kat arttırdığı bulunmuştur (37). NIH-AARP diyet ve sağlık çalışması ile alkol ile BHK arasındaki ilişki araştırılmıştır. Hafif (0-5 gr/gün), orta (15$30 \mathrm{gr} / \mathrm{gün}$ ) ve yüksek (30 gr/gün üzerinde) alkol alımı ile BHK gelişim riski karşılaşııııldığında; alkol kullanımının riski erkeklerde 0,75 den $0,71^{\prime} \mathrm{e}$, kadınlarda 0,67 den $0,43^{\prime} \mathrm{e}$ geriletmekte olduğu saptanmıştır (38). Kahve ve çay tüketimi ile BHK arasında bir ilişki saptanamamış (39) olmasının yanında ters bir ilişkinin var olduğunu bildiren çalışmalar da bulunmaktadır (40).

\section{Meslek ile ilişkili Faktörler}

Meslekle ilgili maruziyetlerin BHK ile ilişkili olduğuna dair çalışmalar bulunmaktadır. Bunlardan bir tanesi asbest maruziyeti olup hastanın kendi ifade ettiği maruziyet ile BHK gelişme riskinin 1,4 kat arttığını bildirilmektedir. Bu risk kadmiyum maruziyetinde 2 kat, kuru temizlemede kullanılan çözeltilere maruziyette 1,4 kat, benzin ve diğer petrol ürünlerine maruziyette 1,6 kat artmaktadır (41). Daha sonra yapılan bir meta-analizde asbestin BHK gelişimindeki rolünün daha az önemli olabileceğini (42), bir başka meta-analizde de anlamlı ilişki bulunmadığı belirtilmiştir (43) Trichloroethylene (TCE) endüstriyel bir çözelti olup metal üzerindeki yağların temizlenmesinde kullanılır. Endüstride yaygın maruziyet söz konusu olup bu kişilerde böbrek kanseri sıklığının 8 kat arttığı bildirilmiştir (44). Başka çalışmalarda bu bilgi desteklenmekle beraber riskin daha düşük olabileceği belirtilmektedir, ayrıca etkinin doza bağımlı olduğu ve yüksek dozda maruziyet ile BHK gelişme riskinin 2 kat arttığı 
vurgulanmaktadır (45). TCE maruziyetinin BHK yol açmasında etki mekanizması net değildir. Bu kimyasalın Von Hippel Lindau (VHL) gen mutasyonuna yol açtığını belirten çalışmalar (46) olduğu gibi bu hastalarda VHL gen mutasyonunu sık olmadığını bildiren çalışmalarda bulunmaktadır (47).

Son dönem böbrek hastalığında nedeniyle hemodiyaliz uygulanan ve böbreğin kazanılmış kistik hastalığı gelişen hastalarda da BHK gelişme riski normal popülasyona göre artmıştır (48). Tümörler bilateral ve çok sayıda görülebilir.

BHK'da \%2 olgu aileseldir (11). Özellikle bazı genetik hastalıklar BHK için önemli bir risk grubunu oluşturur. VHL sendromu, kalıtsal papiller BHK, kalıtsal leiomyomatozis-BHK, Birt-HoggDube sendromu, kalıtsal renal onkositom, kromozom 3 translokasyonu, tubero sklerozis ve kalitsal paraganglioma BHK görülme riskinin arttığı genetik hastalıklardır (49).

\section{Sonuçlar}

BHK görülme sıklığının artması ve daha erken evrede tanı konulmasına karşın mortalite oranlarının halen düşmediği açıktır. Çevresel ve düzeltilebilir faktörler malignitelerin gelişmesinde etkendir. Bu faktörlerden uzak durularak riskte azalma söz konusu olabilmektedirler. Etyolojide rol alan risk faktörlerinin belirlenerek bunlarla mücadele edilmesi ve risk grubundaki kişilerin bilgilendirilmesi BHK görülme sıklığındaki artışın azaltılması için alınacak önlemlerdir. Tütün kullanımı doza bağlı olarak BHK gelişme riskini arttırmaktadır. Pasif maruziyetinde önemli olduğu vurgulanmaktadır. Tütün kullanımının terkedilmesinden uzun yıllar sonra risk azalmaktadır. Tütün kullanımının önlenmesi proflaksi için yapılabilecek en etkili yöntemdir. Obezite ve kan basıncı yüksekliği diğer önemli faktörler olup obezitenin önlenmesi, kan basıncı yüksekliğinin etkin tedavisi alınabilecek diğer koruyucu önlemlerdir. Mesleki faktörlerin mevcudiyeti bu iş kollarında çalışan işçilerin ve iş verenlerin bilgilendirilerek iş güvenliği konusunda gerekli önlemlerin alınmasına ışık tutacaktır.

\section{Çıkar çatışması: Yazarlar bu makale ile ilgili olarak herhangi bir çıkar çatışması bildirmemişlerdir.}

\section{Kaynaklar}

1. European Network of Cancer Registries. Eurocim version 4.0. European incidence database V2.3, 730 entity dictionary (2001), Lyon, 2001.

2. Lindblad P. Epidemiology of renal cell carcinoma. Scand J Surg 2004;93:88-96.

3. Ferlay J, Steliarova-Foucher E, Lortet-Tieulent J, et al. Cancer incidence and mortality patterns in Europe: estimates for 40 countries in 2012. Eur J Cancer 2013;49:1374-1403.

4. Patard JJ, Rodriguez A, Rioux-Leclercq N, et al. Prognostic significance of the mode of detection in renal tumours. BJU Int 2002;90:358-363.

5. Kato M, Suzuki T, Suzuki $Y$, et al. Natural history of small renal cell carcinoma: evaluation of growth rate, histological grade, cell proliferation and apoptosis. J Urol 2004;172:863-866.

6. Tsui $\mathrm{KH}$, Shvarts $\mathrm{O}$, Smith RB, et al. Renal cell carcinoma: prognostic significance of incidentally detected tumors. JUrol 2000; 163:426-430.

7. Chow WH, Linehan WM, Devesa SS. Re: Rising incidence of small renal masses: A need to reassess treatment effect. J Natl Cancer Inst 2007;99:569-570.

8. American Cancer Society. Cancer Facts \& Figures 2014. Atlanta, Ga: American Cancer Society; 2014.
9. Ferlay J, Shin HR, Bray F, et al. GLOBOCAN 2008 v1.2, Cancer Incidence and mortality Worldwide: IARC CancerBase No. 10 (Internet). 2008 [cited 2011 28/8/2011].

10. Aron $M$, Nguyen MM, Stein RJ, et al. Impact of gender in renal cell carcinoma: An analysis of SEER database. Eur Urol 2008;54:133-140.

11. Lipworth L, Tarone RE, McLaughlin JK. The epidemiology of renal cell carcinoma. J Urol 2006;176:2353-2358.

12. Clague J, Lin J, Cassidy A, et al. Family history and risk of renal cell carcinoma: results from a case-control study and systematic metaanalysis. Cancer Epidemiol Biomarkers Prev 2009;18:801-807.

13. International Agency for Research on cancer (IARC). WHO IARC monographs. Vol. 83, 2004.

14. Bergstrom A, Hsieh CC, Lindblad $P$, et al. Obesity and renal cell cancer-a quantitative review. $\mathrm{Br}$ J Cancer 2001;85:984-990.

15. Pischon $\mathrm{T}$, Lahmann $\mathrm{PH}$, Boeing $\mathrm{H}$, et al. Body size and risk of renal cell carcinoma in the European Prospective Investigation into Cancer and Nutrition (EPIC). Int J Cancer 2006;118:728-738.

16. Weikert $\mathrm{S}$, Boeing $\mathrm{H}$, Pischon $\mathrm{T}$, et al. Blood pressure and risk of renal cell carcinoma in the European prospective investigation into cancer and nutrition. Am J Epidemiol 2008;167:438-446.

17. Hunt JD, van der Hel OL, McMillan GP, et al. Renal cell carcinoma in relation to cigarette smoking: meta-analysis of 24 studies. Int J Cancer. 2005;114:101-108.

18. Coughlin SS, Neaton JD, Randall B, et al. Predictors of mortality from kidney cancer in 332,547 men screened for the Multiple Risk Factor Intervention Trial. Cancer 1997;79:2171-2177.

19. Theis RP, Dolwick Grieb SM, Burr D, et al. Smoking, environmental tobacco smoke, and risk of renal cell cancer: a population-based case-control study. BMC Cancer 2008;8:387.

20. Sawada N, Inoue M, Sasazuki S, et al. Body mass index and subsequent risk of kidney cancer: a prospective cohort study in Japan. Ann Epidemiol. 2010;20:466-472.

21. Calle EE, Kaaks R. Overweight, obesity and cancer: epidemiological evidence and proposed mechanisms. Nat Rev Cancer 2004;4:579-591.

22. Renehan AG, Tyson $M$, Egger $M$, et al. Body-mass index and incidence of cancer: a systematic review and meta-analysis of prospective observational studies. Lancet 2008;371:569-578.

23. Gago-Dominguez M, Castelao JE, Yuan JM, et al. Lipid peroxidation: a novel and unifying concept of the etiology of renal cell carcinoma (United States). Cancer Causes Control 2002;13:287-293.

24. Osório-Costa F, Rocha GZ, Dias MM, et al. Epidemiological and molecular mechanisms aspects linking obesity and cancer. Arq Bras Endocrinol Metabol 2009;53:213-226.

25. McLaughlin JK, Chow WH, Mandel JS, et al. International renalcell cancer study. VIII. Role of diuretics, other anti-hypertensive medications and hypertension. Int J Cancer 1995;63:216-221.

26. Fryzek JP, Poulsen AH, Johnsen SP, et al. A cohort study of antihypertensive treatments and risk of renal cell cancer. Br J Cancer 2005;92:1302-1306.

27. Weikert S, Boeing $\mathrm{H}$, Pischon $\mathrm{T}$, et al. Blood pressure and risk of renal cell carcinoma in the European prospective investigation into cancer and nutrition. Am J Epidemiol 2008; 167:438-446.

28. Chow WH, Gridley G, Fraumeni JF Jr, et al. Obesity, hypertension, and the risk of kidney cancer in men. N Engl J Med 2000;343:1305-1311.

29. McLaughlin JK, Lipworth L. Epidemiologic aspects of renal cell cancer. Semin Oncol 2000;27:115-123.

30. McCredie M, Pommer W, McLaughlin JK, et al. International renalcell cancer study. II. Analgesics. Int J Cancer 1995;60:345-349.

31. Tavani A, Zucchetto A, Dal Maso L, et al. Lifetime physical activity and the risk of renal cell cancer. Int J Cancer 2007;1 20:1977-1980.

32. Moore SC, Chow WH, Schatzkin A, et al. Physical activity during adulthood and adolescence in relation to renal cell cancer. Am J Epidemiol 2008;168:149-157. 
33. Lee JE, Spiegelman D, Hunter DJ, et al. Fat, protein, and meat consumption and renal cell cancer risk: a pooled analysis of 13 prospective studies. J Natl Cancer Inst 2008;100:1695-1706.

34. Allen NE, Roddam AW, Sieri S, et al. A prospective analysis of the association between macronutrient intake and renal cell carcinoma in the European Prospective Investigation into Cancer and Nutrition. Int J Cancer 2009;125:982-987.

35. Lee JE, Männistö S, Spiegelman D, et al. Intakes of fruit, vegetables, and carotenoids and renal cell cancer risk: a pooled analysis of 13 prospective studies. Cancer Epidemiol Biomarkers Prev 2009;18:1730-1739.

36. Bertoia M, Albanes D, Mayne ST, et al. No association between fruit, vegetables, antioxidant nutrients and risk of renal cell carcinoma. Int J Cancer 2010;126:1504-1512.

37. Galeone C, Pelucchi C, Maso LD, et al. Glycemic index, glycemic load and renal cell carcinoma risk. Ann Oncol 2009;20:1881-1885.

38. Lew JQ, Chow WH, Hollenbeck AR, et al. Alcohol consumption and risk of renal cell cancer: the NIH-AARP diet and health study. $\mathrm{Br} J$ Cancer 2011;104:537-541.

39. Montella M, Tramacere I, Tavani A, et al. Coffee, decaffeinated coffee, tea intake, and risk of renal cell cancer. Nutr Cancer 2009;61:76-80.

40. Lee JE, Hunter DJ, Spiegelman D, et al. Intakes of coffee, tea, milk, soda and juice and renal cell cancer in a pooled analysis of 13 prospective studies. Int J Cancer 2007;121:2246-2253.

41. Mandel JS, McLaughlin JK, Schlehofer B, et al. International renal-cell cancer study. IV. Occupation. Int J Cancer 1995;61:601-605.
42. Sali D, Boffetta P. Kidney cancer and occupational exposure to asbestos: a meta-analysis of occupational cohort studies. Cancer Causes Control 2000;11:37-47.

43. Goodman M, Morgan RW, Ray R, et al. Cancer in asbestos-exposed occupational cohorts: a meta-analysis. Cancer Causes Control 1999;10:453-465.

44. Henschler $D$, Vamvakas $S$, Lammert $M$, et al. Increased incidence of renal cell tumors in a cohort of cardboard workers exposed to trichloroethene. Arch Toxicol 1995;69:291-299.

45. Charbotel B, Fevotte J, Hours M, et al. Case-control study on renal cell cancer and occupational exposure to trichloroethylene. Part II: Epidemiological aspects. Ann Occup Hyg 2006;50:777-787.

46. Brauch $\mathrm{H}$, Weirich $\mathrm{G}$, Klein $\mathrm{B}$, et al. VHL mutations in renal cell cancer: does occupational exposure to trichloroethylene make a difference? Toxicol Lett 2004;151:301-310.

47. Charbotel B, Gad S, Caïola D, et al. Trichloroethylene exposure and somatic mutations of the VHL gene in patients with Renal Cell Carcinoma. J Occup Med Toxicol 2007;2:13.

48. Stewart JH, Buccianti G, Agodoa L, et al. Cancers of the kidney and urinary tract in patients on dialysis for end-stage renal disease: analysis of data from the United States, Europe, and Australia and New Zealand. J Am Soc Nephrol 2003;14:197-207.

49. Axwijk PH, Kluijt I, de Jong $D$, et al. Hereditary causes of kidney tumours. Eur J Clin Invest 2010;40:433-439. 